\title{
Irrigation Requirements for Seed Production of Three Leguminous Wildflowers of the U.S. Intermountain West
}

\author{
Clinton C. Shock ${ }^{1,7}$, Erik B. G. Feibert ${ }^{2}$, Alicia Rivera ${ }^{3}$, \\ and Lamont D. Saunders ${ }^{4}$ \\ Malheur Experiment Station, Oregon State University, 595 Onion Avenue, \\ Ontario, OR 97914
}

\section{Nancy Shaw ${ }^{5}$ and Francis F. Kilkenny ${ }^{6}$ \\ U.S. Forest Service, Rocky Mountain Research Station, 322 East Front Street, Suite 401, Boise, ID 83702 \\ Additional index words. subsurface drip irrigation, rangeland restoration, Dalea ornata, Dalea searlsiae, Astragalus filipes}

\begin{abstract}
Increasing the supply of native wildflower seed is essential for restoring burned and degraded wildlands in the Intermountain West. Limitations to wildland seed collection necessitate development of effective cultural practices to improve reliability of seed production in agricultural fields. Irrigation trials were conducted over multiple years for three perennial species in the Fabaceae family [Dalea ornata (Douglas ex Hook.) Eaton \& J. Wright, Dalea searlsiae (A. Gray) Barneby, and Astragalus filipes Torr. ex A. Grayl. Each of the three species was grown at the Oregon State University Malheur Experiment Station, Ontario, OR and received 0, 100, or $200 \mathrm{~mm} \cdot \mathrm{year}^{-1}$ of drip irrigation in four equal biweekly increments during bud formation and flowering. Seed yield responses to irrigation were evaluated by linear and quadratic regression against 1) applied water, 2) applied water plus spring precipitation, 3) applied water plus winter and spring precipitation, and 4) applied water plus fall, winter, and spring precipitation. In general, seed yields responded quadratically to irrigation. Adding fall, winter, and spring precipitation to applied water improved the accuracy of estimated water requirements for maximum seed production of $D$. ornata and $D$. searlsiae. For $D$. ornata, the highest yields averaged $396 \mathrm{~kg} \cdot \mathrm{ha}^{-1}$ and ranged from 146 to $545 \mathrm{~kg} \cdot \mathrm{ha}^{-1}$. Averaged over 6 years, seed yield of $D$. ornata was highest with applied water plus fall, winter, and spring precipitation totaling $393 \mathrm{~mm}$. For D. searlsiae, the highest yields averaged 260 $\mathrm{kg} \cdot \mathrm{ha}^{-1}$ and ranged from 51 to $424 \mathrm{~kg} \cdot \mathrm{ha}^{-1}$. Averaged over 6 years, seed yield of $D$. searlsiae was highest with applied water plus fall, winter, and spring precipitation totaling $412 \mathrm{~mm}$. Seed yields of $A$. filipes ranged from 7 to $110 \mathrm{~kg} \cdot \mathrm{ha}^{-1}$ depending on year and averaged $40 \mathrm{~kg} \cdot \mathrm{ha}^{1}$ over 6 years. Seed yields of $A$. filipes did not respond to irrigation in any of the 5 years of testing.
\end{abstract}

Restoration of lands in the Intermountain West following wildfire or disturbances resulting from mining, energy development, or other human activities requires increased

Received for publication 16 Jan. 2018. Accepted for publication 21 Feb. 2018

This project was partially funded by the USDA Forest Service, Rocky Mountain Research Station's Great Basin Native Plant Project, USDI Bureau of Land Management, Oregon State University, Malheur County Education Service District, and by Formula Grants 2016-31100-06041 and 2016-31200-06041 from the USDA National Institute of Food and Agriculture.

${ }^{1}$ Professor Emeritus and Director.

${ }^{2}$ Senior Faculty Research Assistant.

${ }^{3}$ Bioscience Research Technician I.

${ }^{4}$ Bioscience Research Technician III.

${ }^{5}$ Research Botanist (Emeritus).

${ }^{6}$ Research Biologist.

${ }^{7}$ Corresponding author. E-mail: clinton.shock@ oregonstate.edu. cannot be obtained through wildland collections (Shaw and Jensen, 2014). Economical commercial production of these species requires development of cultural practices specific to each species (Shock et al., 2015).

Legumes (Fabaceae) are valuable in the Great Basin ecosystem, because they can provide biologically fixed nitrogen to associated species and can enhance forage quality of rangelands. The three species in this study [D. ornata (Douglas ex Hook.) Eaton \& J. Wright, D. searlsiae (A. Gray) Barneby, and A. filipes Torr. ex A. Gray] are long-lived perennials native to the western United States. These three species are important components of rangeland ecosystems of the intermountain West and are nontoxic to herbivores (Bhattarai et al., 2008, 2010). Dalea ornata and $A$. filipes occur in the northern Intermountain area and D. searlsiae is found in southwestern Intermountain area.

These species are dormant in the winter. Shoots of these plants grow from the crown of a taproot in early spring using the natural moisture from snow melt and spring rain. Vegetative growth, flowering, and seed set are complete by late spring to early summer. Some species of the genus Astragalus are eaten by sage-grouse chicks (Drut et al., 1994) and by bighorn sheep in northwestern Mexico (Tarango, et al., 2002). Plants of the genus Dalea are likely preferred by sage-grouse (Stiver et al., 2015). Astragalus and Dalea are recommended to provide habitat for pollinators (Cane and Love, 2016). The three species included in this research and likely other members of these genera are tolerant of burning and provide nectar for recovering bee populations by the first or second year after fire (B. Love and J.H. Cane, personal communication).

Commercial seed production of Dalea spp. and Astragalus spp. is needed for use in rangeland restoration plantings within their native ranges in the Intermountain West, but these species are rarely cultivated, and cultural practices for seed production are largely unknown. A major limitation to economically viable commercial production of Dalea spp. and A. filipes seed is achieving stable and consistent seed production from year to year. In native rangelands, natural variation in spring rainfall and soil moisture results in highly unpredictable water stress at flowering, seed set, and seed development, and water stress is known to compromise seed yield and quality for many plant species.

Native wildflowers are not well adapted to row crop production practices. Supplemental water can be provided by sprinkler or furrow irrigation systems, but these irrigation systems risk encouraging weeds and fungal pathogens. Subsurface drip irrigation can reduce wetting of the soil surface and could reduce weed and disease pressure.

The trials reported here tested the effects of three low rates of subsurface drip irrigation on the seed yield of D. ornata, D. searlsiae, and A. filipes. The optimum amount of irrigation for each species was evaluated based not only on the amount of irrigation but also on the amount of seasonal precipitation each year. 


\section{Materials and Methods}

Irrigation trials for D. ornata, D. searlsiae, and A. filipes were started in 2009 at the Malheur Experiment Station of Oregon State University, Ontario, OR at $43^{\circ} 58^{\prime} 42.3^{\prime \prime} \mathrm{N}$, $117^{\circ} 1^{\prime} 26.8^{\prime \prime} \mathrm{W}$ at $689 \mathrm{~m}$ elevation. Annual precipitation averaged $249 \mathrm{~mm}$ during the study, ranging from 179 to $292 \mathrm{~mm}$. The Nyssa silt loam (coarse-silty, mixed, mesic, and Xeric Haplodurid) was bedded into $76-\mathrm{cm}$ rows and four rows were planted to each species. Most of the field lacked topsoil because of land leveling in the 1950s. The analysis of a soil sample taken on 22 Nov. 2005 indicated a $\mathrm{pH}$ of $8.3,1.09 \%$ organic matter, $12 \mathrm{ppm}$ phosphorus (P), $438 \mathrm{ppm}$ potassium, $27 \mathrm{ppm} \mathrm{SO}_{4}-\mathrm{S}, 4370 \mathrm{ppm}$ calcium, $456 \mathrm{ppm}$ magnesium, $81 \mathrm{ppm}$ sodium, $1.6 \mathrm{ppm}$ zinc ( $\mathrm{Zn}), 0.6 \mathrm{ppm}$ copper, 4 ppm manganese, $3 \mathrm{ppm}$ iron (Fe), and $0.6 \mathrm{ppm}$ boron.

Drip tape (T-Tape TSX 515-16-340) was buried at $30-\mathrm{cm}$ depth and spaced $1.52 \mathrm{~m}$ apart beneath alternating interrow spaces. The flow rate for the drip tape was 4.16 $\mathrm{L} \cdot \mathrm{min}^{-1}$ per $100 \mathrm{~m}$ of tape at $55 \mathrm{kPa}$ with emitters spaced $41 \mathrm{~cm}$ apart, resulting in a water application rate of $1.7 \mathrm{~mm} \cdot \mathrm{h}^{-1}$. Water was filtered through sand media filters. Application durations were controlled automatically as described in the following paragraphs.

Seed of each species came from pooled wild collections made by USDA Agricultural Research Service employees. Seeds of $D$. ornata, D. searlsiae, and A. filipes were planted on 25 Nov. 2009 in four rows spaced $76 \mathrm{~cm}$ apart using a custom-made small-plot grain drill with disk openers. Rows of seeds were $38 \mathrm{~cm}$ to each side of the buried drip tapes. Seed was planted on the soil surface with $65-100$ seeds $/ \mathrm{m}$ of row. After planting, sawdust was applied in a narrow band over the seed row at $24 \mathrm{~g} \cdot \mathrm{m}^{-1}$ of row. Following planting and sawdust application, the beds were covered with rowcover (N-sulate; DeWitt Co., Inc., Sikeston, MO). Each rowcover extended across two rows and was applied with a mechanical plastic mulch layer. The field was irrigated for $24 \mathrm{~h}$ on 2 Dec. 2009 because of very dry soil conditions. After the newly planted wildflowers emerged, the rowcover was removed in Apr. 2010. The variable irrigation treatments were not applied to these legumes until 2011.

In Apr. 2011, each legume strip was divided into twelve 9.1-m-long plots. Each plot contained four rows spaced $76 \mathrm{~cm}$ apart. The irrigation experimental design for each species had a randomized complete block design with four replications.

The three irrigation treatments were $0 \mathrm{~mm} \cdot$ year $^{-1}$ (control), $100 \mathrm{~mm} \cdot \mathrm{year}^{-1}$, and $200 \mathrm{~mm} \cdot$ year $^{-1}$ of additional water. The 100 and $200-\mathrm{mm}$ irrigation treatments received four irrigations, 2 weeks apart, starting at the beginning of flowering. Each irrigation supplied $25 \mathrm{~mm}$ (100-mm treatment) or $50 \mathrm{~mm}$ (200-mm treatment) of water. The drip irrigation system was designed to allow separate irrigation of the species because of different timings of flowering and seed formation. The irrigation treatments of the two Dalea spp. were applied together. The A. filipes was irrigated separately to correspond to its flowering and seed set dates. Flowering dates for each species were recorded and are reported in conjunction with the irrigation dates in Table 1.

Weeds were controlled primarily with cultivation and hand rouging. Harvested seed pods of $D$. ornata, $D$. searlsiae, and A. filipes were extensively damaged from feeding by seed beetles in 2013 (Cane et al., 2013). Damage was observed in 2014, but to a lesser degree than in 2013. Control measures were started in 2015 for $D$. ornata and D. searlsiae. Adult weevils were observed on flowers in mid-May 2015. On 21 May 2015, Capture ${ }^{\circledR} 2 \mathrm{EC}$ (bifenthrin) at 0.05 $\mathrm{kg}$ a.i./ha and Rimon ${ }^{\circledR}$ (novaluron) at $0.04 \mathrm{~kg}$ a.i./ha were broadcast sprayed in the evening to minimize harm to pollinators. On 28 May 2015, $\operatorname{Rimon}^{\circledR}$ at $0.04 \mathrm{~kg}$ a.i./ha was again broadcast sprayed in the evening to minimize harm to pollinators. Seed beetles were not observed during flowering in 2016.

Seed yield was determined by a manual once-over harvest of all seed stalks in the middle $7.5 \mathrm{~m}$ of the two center rows of the four-row plots. The seed was cleaned from stalks and chaff and weighed. Seed yield responses to irrigation were evaluated by linear and quadratic regression. Seed yield for each species each year was regressed separately against 1) applied water, 2) applied water plus spring precipitation, 3) applied water plus winter and spring precipitation, and 4) applied water plus fall, winter, and spring precipitation. Winter and spring precipitation occurred in the same calendar year that the yield was determined; fall precipitation occurred the previous year. Seed yield $\left(y, \mathrm{~kg} \cdot \mathrm{ha}^{-1}\right)$ in response to irrigation or irrigation plus precipitation ( $x, \mathrm{~mm} / \mathrm{season})$ was estimated by the equation $y=a+b \times x+c \times x^{2}$. For the quadratic equations, the amount of irrigation $\left(x^{\prime}\right)$ that resulted in maximum yield $\left(y^{\prime}\right)$ was calculated using the formula $x^{\prime}=$ $-b \times(2 c)^{-1}$, where $a$ is the intercept, $b$ is the linear parameter, and $c$ is the quadratic parameter and the maximum yield was considered the "highest" yield. For the linear regressions, the highest seed yield for a species in each year was based on the highest measured average seed yield.

Adding the seasonal precipitation to the irrigation response equation would have the potential to provide a closer estimate of the amount of irrigation water required for maximum seed yield for each species each year. Regressions of seed yield for each species each year were calculated on all the sequential seasonal amounts of precipitation and irrigation, but only the regressions that improved the estimated water requirements are reported in the following paragraphs. For each species, the period of precipitation plus applied water that had the lowest standard deviation for irrigation plus precipitation over the years was chosen as the most reliable independent variable for predicting seed yield. To compare yield responses over years, regressions were also made on the relative seed yields compared with irrigation plus precipitation. Relative seed yield for each plot was calculated

Table 1. Flowering, irrigation, and seed harvest dates for three wildflower species grown at the Oregon State University Malheur Experiment Station, Ontario, OR, 2011-16.

\begin{tabular}{|c|c|c|c|c|c|c|c|}
\hline \multirow[b]{2}{*}{ Species } & \multirow[b]{2}{*}{ Yr } & \multicolumn{3}{|c|}{ Flowering dates } & \multicolumn{2}{|c|}{ Irrigation dates } & \multirow[b]{2}{*}{ Harvest date } \\
\hline & & Start & Peak & End & Start & End & \\
\hline \multirow[t]{6}{*}{ Dalea searlsiae } & 2011 & 8 June & 20 June & 20 July & 27 May & 6 July & 21 July \\
\hline & 2012 & 23 May & 10 June & 30 June & 11 May & 21 June & 10 July \\
\hline & 2013 & 13 May & & 15 June & 8 May & 19 June & 29 June \\
\hline & 2014 & 15 May & 4 June & 24 June & 6 May & 17 June & 1 July \\
\hline & 2015 & 13 May & 26 May & 16 June & 5 May & 17 June & 22 June \\
\hline & 2016 & 11 May & 28 May & 10 June & 3 May & 14 June & 16 June \\
\hline \multirow[t]{6}{*}{ Dalea ornata } & 2011 & 8 June & 20 June & 20 July & 27 May & 6 July & 22 July \\
\hline & 2012 & 23 May & 10 June & 30 June & 11 May & 21 June & 11 July \\
\hline & 2013 & 13 May & 21 May & 15 June & 8 May & 19 June & 28 June \\
\hline & 2014 & 15 May & 4 June & 24 June & 6 May & 17 June & 1 July \\
\hline & 2015 & 5 May & 26 May & 22 June & 5 May & 17 June & 25 June \\
\hline & 2016 & 3 May & 26 May & 10 June & 3 May & 14 June & 13 June \\
\hline \multirow[t]{5}{*}{ Astragalus filipes } & 2011 & 20 May & 26 May & 30 June & 13 May & 23 June & 18 July \\
\hline & 2012 & $28 \mathrm{Apr}$ & 23 May & 19 June & 11 May & 21 June & 5 July \\
\hline & 2013 & 3 May & 10 May & 25 May & 8 May & 19 June & 28 June \\
\hline & 2014 & 5 May & 13 May & 28 May & 29 Apr. & 10 June & 24 June \\
\hline & 2015 & 17 Apr. & 13 May & 1 June & 21 Apr. & 3 June & 16 June \\
\hline
\end{tabular}

Table 2. Precipitation and growing degree-days at the Malheur Experiment Station, Ontario, OR, $2011-16$.

\begin{tabular}{lccccc}
\hline & \multicolumn{3}{c}{ Precipitation $(\mathrm{mm})$} & & Growing degree-days $\left(10-30^{\circ} \mathrm{C}\right)$ \\
\cline { 2 - 4 } & Spring & Winter + spring & Fall + winter + spring & January to June \\
\hline 2011 & 121 & 235 & 367 & 476 \\
2012 & 66 & 156 & 213 & 682 \\
2013 & 22 & 60 & 135 & 733 \\
2014 & 44 & 130 & 205 & 741 \\
2015 & 82 & 151 & 265 & 895 \\
2016 & 56 & 128 & 255 & 810 \\
72 -year average & 67 & 147 & 230 & \\
\end{tabular}


as the percentage of the yield of the highest yielding treatment for each species for each year. Regressions were also made relating seed yield to growing degree-days.

\section{Results}

Both Dalea species and A. filipes began flowering and producing seed in the second year after fall planting (Table 1). Both precipitation and growing degree-days showed large year-to-year variation (Table 2). Large year-to-year variations in seed yields also occurred for all three species (Table 3). For the Dalea species, seed yields in 2013 were substantially lower than the other years, possibly because of damage from seedfeeding beetles (Cane et al., 2013). Although there were tremendous variations in seed yields over species and years, general tendencies emerged for the mean seed yields for each species and irrigation treatment.

Dalea ornata, blue mountain prairie clover. Seed yields of $D$. ornata exhibited a quadratic response to irrigation amount each year from 2012 to 2016 (Table 4; Fig. 1A-C). In 2011, seed yields of D. ornata

Table 3. Average seed yields of three legume species over multiple years in response to 0,100 , and $200 \mathrm{~mm}$ of irrigation during flowering and seed set, Oregon State University Malheur Experiment Station, Ontario, OR.

\begin{tabular}{|c|c|c|c|c|c|}
\hline \multirow[b]{2}{*}{ Species } & \multirow[b]{2}{*}{ Yr } & $0 \mathrm{~mm}$ & $100 \mathrm{~mm}$ & $200 \mathrm{~mm}$ & Least significant difference $(0.05)$ \\
\hline & & \multicolumn{4}{|c|}{-------------------------------------------------------------- } \\
\hline \multirow{4}{*}{ Dalea searlsiae } & 2012 & 196.6 & 323.5 & 339.4 & 104.8 \\
\hline & 2015 & 247.8 & 370.4 & 385.5 & 76.5 \\
\hline & 2016 & 166.5 & 267.5 & 249.0 & 62.7 \\
\hline & Average & 164.8 & 243.1 & 250.6 & 34.2 \\
\hline \multirow{5}{*}{ Dalea ornata } & 2013 & 32.0 & 117.2 & 146.0 & 43.5 \\
\hline & 2014 & 133.7 & 473.6 & 533.5 & 161.4 \\
\hline & 2015 & 238.4 & 444.3 & 299.3 & 122.8 \\
\hline & 2016 & 275.9 & 344.9 & 349.9 & NS \\
\hline & Average & 225.6 & 365.3 & 371.8 & 81.3 \\
\hline \multirow[t]{2}{*}{ Astragalus filipes } & 2011 & 97.4 & 110.2 & 82.9 & NS \\
\hline & 2012 & 25.4 & 14.1 & 18.0 & NS \\
\hline
\end{tabular}

Table 4. Regression analysis for Dalea ornata seed yield $\left(y, \mathrm{~kg} \cdot \mathrm{ha}^{-1}\right)$ in response to irrigation $(x, \mathrm{~mm} / \mathrm{season})$ using the equation $y=a+b \times x+c \times x^{2}$ in $2011-16$, and 6-year average. Irrigation amounts were 0,100 , and $200 \mathrm{~mm}$. For the quadratic equations, the amount of irrigation that resulted in maximum yield was calculated using the formula $x=-b \times(2 c)^{-1}$, where $\mathrm{b}$ is the linear parameter and $\mathrm{c}$ is the quadratic parameter, Oregon State University Malheur Experiment Station, Ontario, OR.

\begin{tabular}{|c|c|c|c|c|c|c|c|}
\hline \multicolumn{8}{|c|}{ Water applied vs. yield } \\
\hline Yr & Intercept & Linear & Quadratic & $R^{2}$ & $P$ & Highest yield $\left(\mathrm{kg} \cdot \mathrm{ha}^{-1}\right)$ & $\begin{array}{c}\text { Water applied for highest } \\
\text { yield ( } \mathrm{mm} / \text { season) }\end{array}$ \\
\hline$\overline{2011}$ & 509.5 & -0.561 & & 0.11 & NS & 509.5 & 0.0 \\
\hline 2014 & 133.8 & 4.800 & -0.01401 & 0.87 & 0.001 & 545.0 & 171.3 \\
\hline 2015 & 243.4 & 3.612 & -0.01603 & 0.64 & 0.05 & 446.8 & 112.7 \\
\hline 2016 & 275.9 & 2.860 & -0.01245 & 0.55 & 0.10 & 440.2 & 114.9 \\
\hline
\end{tabular}

Water applied plus fall, winter, and spring precipitation vs. yield

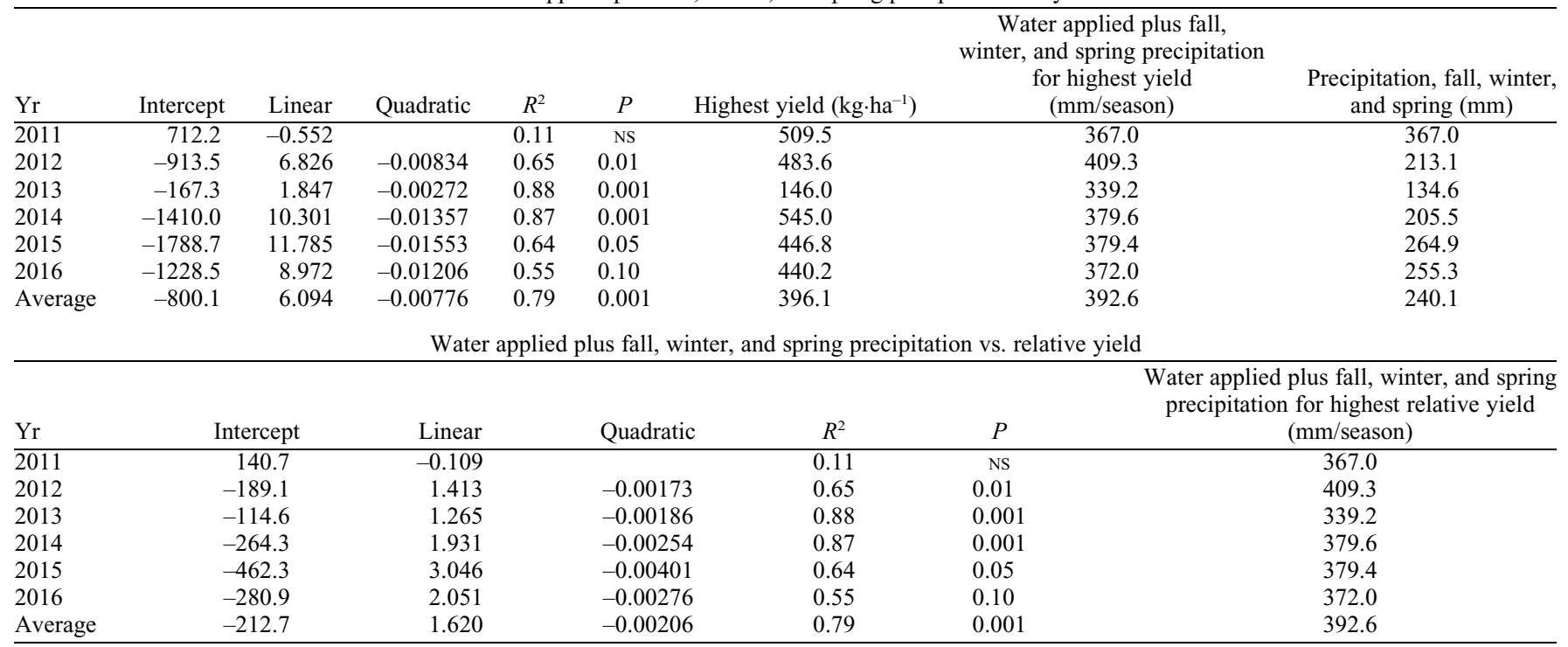


did not respond to irrigation. The year 2011 had the highest fall, winter, and spring precipitation and the lowest number of growing degree-days among the 6 years of testing (Table 2). Of the three periods of precipitation evaluated, adding fall, winter, and spring precipitation to applied water resulted in the least variation in the water requirement for maximum seed production of $D$. ornata. The standard deviation of the estimated optimal amount of water decreased with the duration of the period of precipitation considered: $78.8,57.1,45.6$, and $36.1 \mathrm{~mm}$ for irrigation alone, irrigation plus spring precipitation, irrigation plus winter and spring precipitation, and irrigation plus fall through spring precipitation, respectively. The amount of water applied plus fall, winter, and spring precipitation for maximum seed yield, calculated from the regression equations, ranged from $367 \mathrm{~mm}$ yielding $509 \mathrm{~kg} \cdot \mathrm{ha}^{-1}$ in 2011 to $409 \mathrm{~mm}$ yielding $484 \mathrm{~kg} \cdot \mathrm{ha}^{-1}$ in 2012 . The highest yields averaged $396 \mathrm{~kg} \cdot \mathrm{ha}^{-1}$ and ranged from 146 to $545 \mathrm{~kg} \cdot \mathrm{ha}^{-1}$. Averaged over 6 years, relative seed yield was highest with applied water plus fall, winter, and spring precipitation totaling $393 \mathrm{~mm}$ (Table 4; Fig. 1C). Fall, winter, and spring precipitation provided a substantial amount of the water needed for maximum seed yield, from $40 \%$ in 2013 to $100 \%$ in 2011 .

Dalea searlsiae, Searls' prairie clover. Seed yields of $D$. searlsiae exhibited a quadratic response to irrigation amount in 2012, 2014, 2015, and 2016 (Table 5; Fig. 1DF). In 2011 , seed yields of $D$. searlsiae had a negative linear response to irrigation plus fall, winter, and spring precipitation. The year 2011 had the highest fall, winter, and spring precipitation and the lowest fewest growing degree-days, over the 6 years of testing (Table 2). In 2013, seed yields of D. searlsiae showed a linear positive response to irrigation plus fall, winter, and spring precipitation. The year 2013 had the lowest fall, winter, and spring precipitation over the 6 years of testing. Of the three periods of precipitation evaluated, adding fall, winter, and spring precipitation to applied water resulted in the lowest variation in the optimal water requirement for maximum seed production of $D$. searlsiae. The standard deviation of the estimated optimal amount of water decreased with the duration of the period of precipitation considered: $75.1,48.7,43.7$, and $22.7 \mathrm{~mm}$ for irrigation alone, irrigation plus spring precipitation, irrigation plus winter and spring precipitation, and irrigation plus fall through spring precipitation, respectively. The amount of water applied plus fall, winter, and spring precipitation for maximum seed yield, calculated from the regression equations, ranged from $367 \mathrm{~mm}$ yielding $295 \mathrm{~kg} \cdot \mathrm{ha}^{-1}$ in 2011 to $432 \mathrm{~mm}$ yielding $262 \mathrm{~kg} \cdot \mathrm{ha}^{-1}$ in 2014 . The highest yields averaged $260 \mathrm{~kg} \cdot \mathrm{ha}^{-1}$ and ranged from 51 to $424 \mathrm{~kg} \cdot \mathrm{ha}^{-1}$. Averaged over 6 years, relative seed yield was highest with applied water plus fall, winter, and spring precipitation totaling $412 \mathrm{~mm}$ (Table 5; Fig. 1F). Fall, winter, and spring precipitation provided from $40 \%$ in 2013
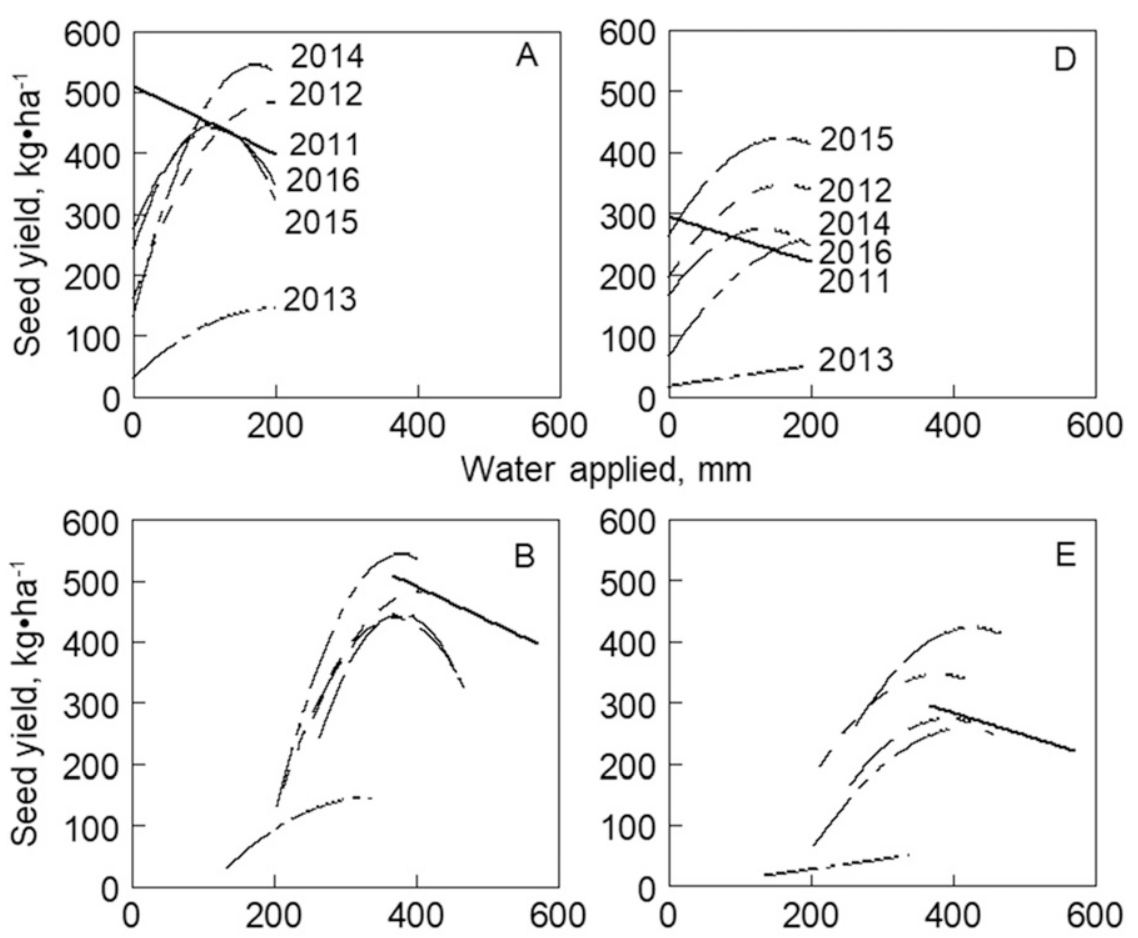

Water applied plus fall, winter, spring precipitation, $\mathrm{mm}$

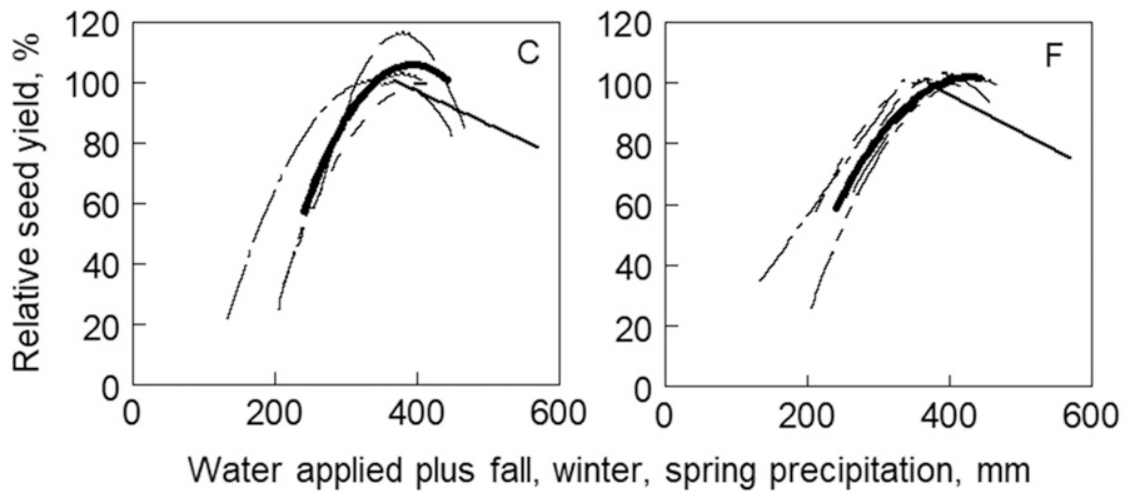

Fig. 1. Seed yield response of Dalea ornata and Dalea searlsiae to irrigation in 2011-16, Oregon State University Malheur Experiment Station, Ontario, OR. The seed yield response of $D$. ornata to applied water (A), water applied plus fall, winter, and spring precipitation (B) are compared with the seed yield response of $D$. searlsiae to applied water $(\mathbf{D})$, water applied plus fall, winter, and spring precipitation (E). The relative seed yield response of D. ornata to water applied plus fall, winter, and spring precipitation $(\mathbf{C})$ is compared with the relative seed yield response of Dalea searlsiae to water applied plus fall, winter, and spring precipitation $(\mathbf{F})$.

to $100 \%$ in 2011 of the water needed for maximum seed yield for $D$. searlsiae as it did for D. ornata.

Astragalus filipes, basalt milkvetch. Seed yields ranged from 7 to $110 \mathrm{~kg} \cdot \mathrm{ha}^{-1}$ depending on the year (Table 3 ). Seed yields averaged 40 $\mathrm{kg} \cdot \mathrm{ha}^{-1}$ over 5 years. Seed yields of $A$. filipes did not respond to irrigation in any of the 5 years of testing (Tables 3 and 6).

\section{Discussion}

Seasonal precipitation varied greatly among years, as did the amount of water required for maximum seed production of $D$. ornata and D. searlsiae. The irrigation requirements for the Dalea species in this study are consistent with the results for Lomatium dissectum (Nutt.) Mathias \& Constance,
Lomatium triternatum (Pursh) J.M. Coult. \& Rose, and Lomatium grayi (J.M. Coult. \& Rose) J.M. Coult. \& Rose (Shock et al., 2012, 2016) and Eriogonum umbellatum Torr., and Eriogonum heracleoides Nutt. (Shock et al., 2017) grown at the same site in that the water requirements for seed production were low and the responses to applied irrigation were quadratic. The regression analyses showed large differences in the optimum amount of water for maximum seed yield among years. When precipitation was added to the amount of water applied, the variability in the optimum amount of water decreased for D. ornata and $D$. searlsiae like the seed yield responses over multiple years described for L. grayi and E. umbellatum, which had highest yields with irrigation plus precipitation 
Table 5. Regression analysis for Dalea searlsiae seed yield $\left(y, \mathrm{~kg} \cdot \mathrm{ha}^{-1}\right)$ in response to irrigation $(x, \mathrm{~mm} / \mathrm{season}) \mathrm{using}$ the equation $y=a+b \times x+\mathrm{c} \times x^{2}$ in $2011-16$, and 6-year averages. Irrigation amounts were 0,100 , and $200 \mathrm{~mm}$. For the quadratic equations, the amount of irrigation that resulted in maximum yield was calculated using the formula $x=-b / 2 c$, where $b$ is the linear parameter and $c$ is the quadratic parameter, Oregon State University Malheur Experiment Station, Ontario, OR.

\begin{tabular}{|c|c|c|c|c|c|c|c|}
\hline \multicolumn{8}{|c|}{ Water applied vs. yield } \\
\hline $\mathrm{Yr}$ & Intercept & Linear & Quadratic & $R^{2}$ & $P$ & Highest yield $\left(\mathrm{kg} \cdot \mathrm{ha}^{-1}\right)$ & Water applied for highest yield ( $\mathrm{mm} / \mathrm{season})$ \\
\hline$\overline{2011}$ & 294.8 & -0.372 & & 0.49 & 0.05 & 294.8 & 0.0 \\
\hline 2012 & 196.6 & 1.825 & -0.00555 & 0.62 & 0.05 & 346.5 & 164.3 \\
\hline 2013 & 17.4 & 0.166 & & 0.54 & 0.01 & 51.0 & 203.0 \\
\hline 2014 & 67.2 & 1.754 & -0.00395 & 0.79 & 0.001 & 262.1 & 222.2 \\
\hline 2015 & 264.5 & 1.982 & -0.00617 & 0.56 & 0.05 & 423.6 & 160.6 \\
\hline 2016 & 166.5 & 1.607 & -0.00597 & 0.56 & 0.05 & 274.6 & 134.5 \\
\hline Average & 167.8 & 1.088 & -0.00322 & 0.63 & 0.05 & 259.7 & 169.0 \\
\hline
\end{tabular}

Water applied plus fall, winter, and spring precipitation vs. yield

\begin{tabular}{|c|c|c|c|c|c|c|c|c|}
\hline $\mathrm{Yr}$ & Intercept & Linear & Quadratic & $R^{2}$ & $P$ & Highest yield $\left(\mathrm{kg} \cdot \mathrm{ha}^{-1}\right)$ & $\begin{array}{c}\text { Water applied plus fall, winter, and } \\
\text { spring precipitation for } \\
\text { highest yield ( } \mathrm{mm} / \text { season) }\end{array}$ & $\begin{array}{c}\text { Precipitation, fall, } \\
\text { winter, and spring }(\mathrm{mm})\end{array}$ \\
\hline 2011 & 429.2 & -0.366 & & 0.49 & 0.05 & 294.8 & 367.0 & 367.0 \\
\hline 2012 & -430.6 & 4.089 & -0.00538 & 0.62 & 0.05 & 346.5 & 380.0 & 213.1 \\
\hline 2013 & -4.6 & 0.163 & & 0.54 & 0.01 & 50.5 & 337.6 & 134.6 \\
\hline 2014 & -448.9 & 3.297 & -0.00382 & 0.79 & 0.001 & 262.1 & 431.3 & 205.5 \\
\hline 2015 & -671.8 & 5.118 & -0.00598 & 0.56 & 0.05 & 423.6 & 428.1 & 264.9 \\
\hline 2016 & -614.1 & 4.535 & -0.00579 & 0.56 & 0.05 & 274.6 & 391.9 & 255.3 \\
\hline Average & -268.8 & 2.567 & -0.00312 & 0.63 & 0.05 & 259.7 & 411.8 & 240.1 \\
\hline
\end{tabular}

Water applied plus fall, winter, and spring precipitation vs. relative yield

\begin{tabular}{|c|c|c|c|c|c|c|}
\hline Yr & Intercept & Linear & Quadratic & $R^{2}$ & $P$ & $\begin{array}{l}\text { Water applied plus fall, winter, and spring precipitation } \\
\text { for highest relative yield ( } \mathrm{mm} / \text { season) }\end{array}$ \\
\hline$\overline{2011}$ & 145.9 & -0.124 & & 0.49 & 0.05 & $\begin{array}{l}67.0 \\
\end{array}$ \\
\hline 2012 & -126.9 & 1.205 & -0.00159 & 0.62 & 0.05 & 380.0 \\
\hline 2013 & -9.3 & 0.328 & & 0.54 & 0.01 & 337.6 \\
\hline 2014 & -172.6 & 1.268 & -0.00147 & 0.79 & 0.001 & 431.3 \\
\hline 2015 & -149.7 & 1.165 & -0.00135 & 0.56 & 0.05 & 428.1 \\
\hline 2016 & -229.6 & 1.695 & -0.00216 & 0.56 & 0.05 & 391.9 \\
\hline Average & -120.2 & 1.037 & -0.00121 & 0.63 & 0.05 & 411.8 \\
\hline
\end{tabular}

Table 6. Regression analysis for Astragalus filipes seed yield $\left(y, \mathrm{~kg} \cdot \mathrm{ha}^{-1}\right)$ in response to irrigation $(x, \mathrm{~mm} / \mathrm{season}) \mathrm{using}$ the equation $y=a+b \times x+c \times x^{2}$ in $2011-15$, and 5-year averages. Irrigation amounts were 0, 100, and $200 \mathrm{~mm}$. For the quadratic equations, the amount of irrigation that resulted in maximum yield was calculated using the formula $x=-b / 2 c$, where $b$ is the linear parameter and $c$ is the quadratic parameter, Oregon State University Malheur Experiment Station, Ontario, OR.

\begin{tabular}{|c|c|c|c|c|c|c|c|}
\hline $\mathrm{Yr}$ & Intercept & Linear & Quadratic & $R^{2}$ & $P$ & Highest yield $\left(\mathrm{kg} \cdot \mathrm{ha}^{-1}\right)$ & Water applied for highest yield ( $\mathrm{mm} / \mathrm{season})$ \\
\hline 2011 & 105.3 & -0.081 & & 0.01 & NS & 105.3 & $\begin{array}{l}0.0 \\
\end{array}$ \\
\hline 2012 & 24.7 & -0.041 & & 0.04 & NS & 24.7 & 0.0 \\
\hline 2013 & 11.7 & -0.015 & & 0.03 & NS & 11.7 & 0.0 \\
\hline 2014 & 71.1 & 0.472 & -0.00188 & 0.08 & NS & 100.7 & 125.4 \\
\hline 2015 & 21.4 & -0.039 & & 0.16 & NS & 21.4 & 0.0 \\
\hline Average & 47.2 & -0.016 & & 0.01 & NS & 47.2 & 0.0 \\
\hline
\end{tabular}

totaling 358 and $209 \mathrm{~mm}$, respectively (Shock et al., 2016, 2017). Lomatium dissectum and L. triternatum seed yields were best estimated by a quadratic response to irrigation plus spring precipitation with highest yields at 243 and $255 \mathrm{~mm}$, respectively. Eriogonum heracleoides seed yields were best estimated by a quadratic response to irrigation with no correction for precipitation and with highest yields at $126 \mathrm{~mm}$.

Seed yields of $A$. filipes did not respond to irrigation and were substantially lower than seed yields of the Dalea species. The lack of seed yield response of $A$. filipes to irrigation was similar to the response of Lomatium nudicaule (Pursh) J.M. Coult. \& Rose (Shock et al., 2016). Seed harvest of A. filipes poses a greater challenge than for the Dalea spp. For all three species, a range of seed maturity is present simultaneously among and within plants, and mature seed detaches rapidly from the plant. The variability in seed maturity requires that a single once-over harvest is a compromise between immature, mature, and dehiscing seed. Dalea flowers are arranged in a spike-like cluster of small flowers that bloom from the base to the tip of the cluster. The Dalea floral spikes are initiated over a short period of $\approx 2$ weeks, making a single once-over harvest more feasible. For A. filipes, flowers are initiated individually over a long period, making a single once-over harvest less successful and seed yields lower.

Bhattarai et al. (2008) reported A. filipes seed yields under irrigation in Utah in the range of $0-24 \mathrm{~kg} \cdot \mathrm{ha}^{-1}$. Seed yields in the present study were slightly higher. Bhattarai et al. (2008) also reported that application of imidacloprid insecticide as a soil drench in early June significantly increased seed yields compared with untreated plants. The low seed yields of $A$. filipes in the present study might also be partially related to the lack of seed beetle control. For the Dalea spp., the importance of seed beetle control in the present study is unknown. Seed beetle infestations were present in 2013, 2014, and 2015 . Seed beetle control was only applied in 2015 , but seed yields were only reduced in 2013 compared with other years. It can be difficult to reduce seed damage by controlling ovipositing adults with nonsystemic, short-duration insecticides.

Other studies that examined responses of xerophytic plants to irrigation found similar results within the ranges of irrigation amounts in our study. In Tucson, AZ, with annual precipitation of $293 \mathrm{~mm}$, native grass and native woody plant establishment from seed was optimum with 187-210 mm of irrigation plus precipitation (Roundy et al., 2001). In the Chihuahuan Desert in New Mexico, with annual precipitation of $211 \mathrm{~mm}$, only 6 of 15 species increased vegetative growth in response to $338 \mathrm{~mm}$ of annual irrigation (Gutierrez and Whitford, 1987).

There are few published studies examining seed production of native plants in response to irrigation in arid regions. In a west-central Texas area that receives $530 \mathrm{~mm}$ of annual 
precipitation, Petersen and Ueckert (2005) found that seed production of Atriplex canescens (Pursh) Nutt. (fourwing saltbush) did not respond to either $400 \mathrm{~mm}$ of irrigation in 1 year or $200 \mathrm{~mm}$ of irrigation the next year. In the Owens Valley, CA, with an annual precipitation of $113 \mathrm{~mm}$, Sarcobatus vermiculatus (Hook.) Torr. (greasewood) seed yields were significantly higher when irrigated (Breen and Richards, 2008). These studies were not designed to determine optimum amounts of irrigation for seed yield.

In this study, both Dalea species tested responded to irrigation with increased seed yields. The amount of irrigation plus precipitation needed for maximum Dalea seed yields $\left(300-400 \mathrm{~mm} \cdot \mathrm{year}^{-1}\right)$ was lower than that of irrigation plus precipitation requirements for row crops in the Treasure Valley of Oregon. Treasure Valley crop evapotranspiration ranges from 500 to $800 \mathrm{~mm} \cdot \mathrm{year}^{-1}$ during the spring and summer depending on the crop and year (AgriMet, 2017; Feibert and Shock, 2017). Although Dalea species are perennials, they complete their cycle from sprouting to seed harvest by early July; thus, their irrigation requirements would be expected to be lower than those of annual crops. However, the irrigation requirements for Dalea are low even when compared with an early season crop such as winter wheat (Triticum aestivum L.), which has an average estimated crop evapotranspiration of $633 \mathrm{~mm}$ in the Treasure Valley (Feibert and Shock, 2017).

Studies of cultural practices for native plants are essential to increase seed production and availability of plant material used in restoration of ecosystems in the Intermountain West. Two germplasms of D. ornata have been released, Majestic and Spectrum. One select germplasm of A. filipes has been released, NBR-1. As restoration needs increase, the economic opportunities for native plant seed growers will also increase. Developing in-depth knowledge on seed production practices will support the native seed industry in the future.

\section{Literature Cited}

AgriMet. 2017. Bureau of Reclamation Pacific Northwest Region, Boise, Ida. 18 Nov. 2017. $<\mathrm{http}: / /$ www.usbr.gov/pn/agrimet/>.

Bhattarai, K., D.A. Johnson, T.A. Jones, K.J Connors, and D.R. Gardner. 2008. Physiological and morphological characterization of basalt milkvetch (Astragalus filipes): Basis for plant improvement. Rangeland Ecol. Mgt. 61:444 455.

Bhattarai, K., B.S. Bushman, D.A. Johnson, and J.C. Carman. 2010. Phenotypic and genetic characterization of Blue Mountain prairie clover collections from the western United States. Rangeland Ecol. Mgt. 63:696-706.

Breen, A.N. and J.H. Richards. 2008. Irrigation and fertilization effects on seed number, size, germination and seedling growth: Implications for desert shrub establishment. Oecologia 157:13-19.

Cane, J.H., C. Johnson, J.R. Napoles, D.A. Johnson, and R. Hammon. 2013. Seed-feeding beetles (Bruchinae, Curculionidae, Brentidae) from legumes (Dalea ornata, Astragalus filipes) and other wildflowers needed for restoring rangelands of the Intermountain West. West. N Amer. Nat. 73(4):477-484.

Cane, J.H. and B. Love. 2016. Floral guilds of bees in sagebrush steppe: Comparing bee usage of wildflowers available for postfire restoration. Nat. Areas J. 36:377-391.

Drut, M.S., W.H. Pyle, and J.A. Crawford. 1994. Technical note: Diets and food selection of sage grouse chicks in Oregon. J. Range Mgt. 47:90-93.

Feibert, E.B.G. and C.C. Shock. 2017. 2016 weather report, p. 1-10. In: C.C. Shock (ed.). Oregon State University Agricultural Experiment Station, Malheur Experiment Station Annual Report 2016, Department of Crop and Soil Science Ext/ CrS 157. 25 Oct. 2017. <http://www.cropinfo. net/pdf/ar/2016/2016-001-Weather-Report.pdf $>$.

Gutierrez, J.R. and W.G. Whitford. 1987. Chihuahuan desert annuals: Importance of water and nitrogen. Ecology 68:2032-2045.

Oldfield, S. and P. Olwell. 2015. The right seed in the right place at the right time. Bioscience 65:955-956.
Olwell, P. and L. Riibe. 2016. National seed strategy: Restoring pollinator habitat begins with the right seed in the right place at the right time. Nat. Areas J. 36:363-365.

Petersen, J.L. and D.J. Ueckert. 2005. Fourwing saltbush seed yield and quality: Irrigation, fertilization, and ecotype effects. Rangeland Ecol. Mgt. 58:299-307.

Roundy, B.A., H. Heydari, C.W.S.E. Smith, and B.M.M. Pater. 2001. Summer establishment of Sonoran Desert species for revegetation of abandoned farmland using line source sprinkler irrigation. Arid Land Res. Mgt. 15:23-39.

Shaw, N.L. and S. Jensen. 2014. The challenge of using native plant materials for sagebrush steppe restoration in the Great Basin, USA, p. 141-159. In: K. Kiehl, A. Kirmer, N.L. Shaw, and S. Tischew (eds.). Guidelines for native seed production and grassland restoration. Cambridge Scholars, Newcastle upon Tyne, UK.

Shock, C.C., E.B.G. Feibert, N.L. Shaw, M.P. Shock, and L.D. Saunders. 2015. Irrigation to enhance native seed production for Great Basin restoration. Nat. Areas J. 35(1):74-82.

Shock, M.P., C.C. Shock, E.B.G. Feibert, N.L. Shaw, L.D. Saunders, and R.K. Sampangi. 2012. Cultivation and irrigation of fernleaf biscuitroot (Lomatium dissectum) for seed production. HortScience 47:1525-1528.

Shock, C.C., E.B.G. Feibert, A. Rivera, L.D. Saunders, N.L. Shaw, and F.F. Kilkenny. 2016. Irrigation requirements for seed production of five Lomatium species in a semiarid environment. HortScience 51:1270-1277.

Shock, C.C., E.B.G. Feibert, A. Rivera, L.D. Saunders, N.L. Shaw, and F.F. Kilkenny. 2017. Irrigation requirements for seed production of two Eriogonum species in a semiarid environment. HortScience 52:1188-1194.

Stiver, S.J., E.T. Rinkes, D.E. Naugle, P.D Makela, D.A. Nance, and J.W. Karl. 2015. Sage-Grouse habitat assessment framework: A multiscale assessment tool. Technical reference 6710-1, US Dept. Interior, Bur. Land Mgt., and Western Assn. Fish and Wildlife Agencies, Denver, CO.

Tarango, L.A., P.R. Krausman, R. Valdez, and R.M. Kattnig. 2002. Research observation: Desert bighorn sheep diets in north-western Sonora, Mexico. J. Range Mgt. 55:530-534. 